\title{
Dampak Beasiswa pada Masa Studi Mahasiswa Universitas Al Azhar Indonesia Angkatan 2004-2006
}

\author{
Zaqiatul Mardiah \\ Fakultas Sastra, Universitas Al Azhar Indonesia, Jl. Sisingamangaraja, Jakarta 12110 \\ Tel. 7244456, fax. 7244767, email: zaqiah@uai.ac.id
}

\begin{abstract}
This paper investigates the effect of student aid programs introduced by Alazhar Indonesia University (UAI) on the study duration of bachelor program students who registered at the university in the academic years of $2004-2006$. We apply semiparametric duration model with censored and complete data for this study. Estimation results, using a partial maximum-likelihood technique and considering several risk factors representing student aids, demographic, and individual traits, reveal that student aid programs are significantly abel to explain the variation of student's study duration and also their probability to gaduate from UAI after certain period of study time. In general the higher the period of student aid received, the shorter the student's study period. In addition there is empirical facts that regardless of their traits and characteristics, student's probability to graduate will be bigger when his/her study period has exceed eight semester.
\end{abstract}

Keywords - student aid, duration of study, semiparametric proportional hazard model, relative risk, and hazard rate of graduation

\section{PENGantaR}

Sampai saat ini mayoritas masyarakat Indonesia $N_{\text {masih menganggap bahwa mengikuti }}$ pendidikan tinggi, merupakan sesuatu yang penting bagi diri atau keturunan mereka. Keputusan untuk menjadi salah satu peserta pada program S1, S2, atau S3 pada suatu perguruan tinggi dianggap sebagai investasi untuk masa depan mereka atau keturunan mereka. Dengan menempuh pendidikan tinggi pada strata tertentu, mereka berharap memiliki posisi tawar yang lebih baik di pasar tenaga kerja, dibandingkan para calon pekerja lain, yang hanya berpendidikan menengah, meskipun dengan pengalaman kerja, ketrampilan, dan kemampuan yang setara. Dengan posisi tawar yang lebih baik, mereka berharap dapat memperoleh kompensasi yang lebih baik, dibandingkan pesaingpesaing mereka di pasar tenaga kerja, yang tingkatan pendidikan terakhirnya di bawah mereka.

Dalam ilmu ekonomi, keputusan seseorang untuk menempuh studi di perguruan tinggi dipandang sebagai investasi dalam modal manusia (human capital). Menurut teori standar tentang modal manusia, yang pertama kali diusulkan oleh Becker (1962), masing-masing individu memilih tingkat pendidikan mereka, dalam rangka memaksimalkan nilai saat ini (the discounted present value) dari pendapatan yang mungkin mereka peroleh sepanjang masa, setelah dikurangi dengan biaya-biaya pendidikan. Tingkat pendidikan yang optimal bagi masing-masing individu, dicapai ketika biaya marginal dari tambahan masa studi (dalam satuan tahun), sama dengan nilai saat ini netto (net present value) dari tambahan pendapatan yang mungkin dihasilkan dari tambahan masa studi. Dalam teori ini, biaya marginal dari tambahan masa studi mencakup ongkos hilangnya kesempatan memperoleh pendapatan ketika menempuh studi, dan juga biaya-biaya langsung, seperti biaya operasional pendidikan.

Model sederhana ini memiliki beberapa implikasi. Pertama, biaya investasi pendidikan yang relatif tinggi, diperkirakan membuat tingkat pendidikan optimal yang bisa dicapai relatif rendah.

Berdasarkan implikasi ini, peningkatan dalam biaya langsung, seperti biaya operasional pendidikan, akan menyebabkan rendahnya investasi masyarakat dalam modal manusia. Sebaliknya, penurunan dalam biaya marginal, misalnya karena adanya subsidi pinjaman untuk pendidikan atau bantuan biaya studi, dalam bentuk public grant atau beasiswa, diprediksi akan membuat minat masyarakat untuk menempuh pendidikan pada strata yang lebih tinggi, menjadi lebih tinggi. Kedua, fenomena di pasar tenaga kerja yang menerangkan bahwa semakin tinggi strata 
pendidikan tinggi seseorang, maka kompensasi dan renumerasi yang akan diperoleh juga akan semakin tinggi, diperkirakan akan menyebabkan tingginya minat masyarakat untuk berinvestasi pada strata pendidikan optimal yang lebih tinggi, dan menyelesaikan studi dengan masa yang relatif lebih cepat. Implikasi teoritis dari prediksi kedua ini adalah, besaran ongkos pendidikan tidak menjadi masalah bagi penyandang dana pendidikan, asalkan peserta didik mampu menyelesaikan studi secara tepat waktu, sehingga peluang mereka untuk memperoleh pekerjaan dengan kompensansi benefit yang relatif lebih tinggi, juga semakin besar. Dengan memperoleh kompensasi benefit yang relatif besar, imbal hasil (return) yang dilahirkan dari investasi juga semakin besar. Dalam implikasi ini, masa studi menjadi sesuatu yang penting untuk dipertimbangkan, sebagai salah satu indikator keberhasilan dalam berinvestasi pada pendidikan tinggi, terlepas darimana dana investasi pendidikan itu berasal.

Beberapa prediksi yang diimplikasikan oleh model modal manusia, khususnya yang terkait dengan masa studi pada pendidikan tinggi, sudah lama menjadi topik hangat yang dibahas dalam pustaka-pustaka akademik, khususnya dalam area ekonomi pendidikan (lihat di antaranya di Cameron dan Taber (2004), Shea (2000), Carneiro dan Heckman (2002) atau Kene and Wolpin (2001)). Kerangka teori ekonomi yang diberdayakan untuk memahami perilaku masa studi di perguruan tinggi, pada kajian-kajian mereka, umumnya mengacu pada teori perilaku konsumen dalam menentukan tingkat konsumsi optimal mereka pada berbagai pilihan komoditas, dengan kendala keterbatasan pendapatan yang mereka miliki.

Sejak tahun akademik 2004/2005 Universitas Al Azhar Indonesia (UAI) memperkenalkan program beasiswa kepada para mahasiswa yang sedang menempuh studi di UAI. Prinsip dasar dari program beasiswa ini adalah untuk memberikan kesempatan yang sama kepada para mahasiswa yang berasal dari keluarga yang berpenghasilan menengah atau rendah, atau mereka yang tidak mampu mendanai sendiri biaya perkuliahannya secara penuh, untuk dapat menempuh studi di UAI. Pertimbangan lain yang dikemukakan adalah pemberian beasiswa diharapkan dapat mendorong mahasiswa untuk meningkatkan prestasi akademiknya. Ini dilakukan dengan cara memberikan persyaratan minimal IPK untuk dapat memperoleh beasiswa, selain kondisi keuangan keluarga yang kurang memadai.

Mulai tahun akademik 2006/2007, UAI memperkenalkan skema beasiswa baru, dengan besaran dan cakupan yang lebih baik. Beasiswa ini dinamakan beasiswa nusantara. Beasiswa ini ditawarkan kepada calon mahasiswa baru yang melamar ke UAI. Pertimbangan utama dalam pemberian beasiswa jenis ini adalah kemampuan akademik calon mahasiswa semasa di SMA, dan status sosial dan ekonomi keluarga mahasiswa yang bersangkutan. Beasiswa ini dapat diperoleh mahasiswa sejak semester pertama perkuliahan, hingga maksimal sampai semester kedelapan, dengan catatan bahwa yang bersangkutan dapat mempertahankan indeks prestasi kumulatif (IPK) akademiknya minimal sebesar 3,00 pada setiap tahunnya. Mereka yang memperoleh beasiswa nusantara, akan dibebaskan dari seluruh komponen biaya pendidikan, yaitu biaya BPP, BOP, dan SKS.

Selain itu UAI juga menawarkan beasiswa dengan skema yang lain mulai tahun akademik 2007/2008. Paling tidak, ada dua skema lain yang ditawarkan: (1) beasiswa berbasis prestasi akademik dan kerja, dan (2) beasiswa berbasis kerja.

Mengingat secara ekonomi, pemberian beasiswa merupakan insentif bagi mahasiswa agar dapat menyelesaikan kuliahnya secara tepat waktu, masalah utama yang perlu dievaluasi dari program pemberian beasiswa ini adalah seberapa efektifkah pemberian beasiswa, yang diupayakan oleh pihak UAI, dalam mendukung mahasiswa untuk menyelesaikan studinya secara tepat waktu. Ada banyak kondisi lain, selain pemberian beasiswa, yang secara teoritis juga dapat ikut memengaruhi masa studi mahasiswa. Kondisi-kondisi ini antara lain adalah: karakteristik individu dari mahasiswa yang bersangkutan dan program studi yang dipilih. Meskipun biaya perkuliahannya sama-sama didanai oleh beasiswa, dua mahasiswa dapat berbeda masa studinya karena jenis kelamin mereka berbeda atau program studi yang mereka jalani berbeda. Berdasarkan realitas ini, penelitian diarahkan untuk mengelaborasi beberapa masalah sebagai berikut:

(1) Apakah pemberian beasiswa, efektif dalam mempercepat masa studi mahasiswa, terlepas dari latar belakang dan karakteristik mereka.

(2) Adakah faktor lain yang membantu seorang mahasiswa dapat menyelesaikan studinya secara relatif lebih cepat, selain fasilitas beasiswa yang diperoleh.

(3) Seberapa besar kontribusi pemberian beasiswa dalam memberikan insentif kepada mahasiswa untuk menyelesaikan studinya secara lebih cepat. 


\section{LANDASAN TEORI}

Metode yang paling sering digunakan dalam memahami efek dari keadaaan dan kendala finansial mahasiswa terhadap perilaku masa studinya di perguruan tinggi, adalah metode analisa ekonometrika yang berbasis pada pemodelan hazard dan durasi waktu hingga terjadinya suatu peristiwa.

Dalam tataran teoritis, model ekonomi sederhana tentang alokasi waktu dari seorang siswa, menyatakan bahwa siswa memiliki tiga opsi kegiatan dalam mengalokasikan waktunya. Pertama, ia dapat gunakan untuk bekerja, dengan tujuan untuk mendapatkan penghasilan. Kedua, ia dapat memanfaatkannya hanya untuk studi, dengan harapan dapat mempercepat masa studi dan konsekuensinya dapat meningkatkan tingkat imbal hasil dari investasi dana pendidikan yang dilakukannya, dan ketiga, siswa dapat mengalokasikan waktunya untuk bersenang-senang. Dalam model sederhana ini, kendala yang dihadapi oleh siswa dalam memilih jenis-jenis kegiatan, dari waktu yang tersedia, yang dapat memaksimalkan utilitasnya, berbentuk keterbatasan penghasilan tenaga kerja, pemberian dana dari pihak keluarga atau orang tua, dan bantuan finansial.

Dalam kondisi ketiadaan sistem bantuan finansial yang memadai bagi siswa untuk membantu pendanaan bagi kegiatan perkuliahannya, kendala tambahan, seperti ketiadaan pinjaman dana pendidikan, mungkin dapat muncul disebabkan oleh ketidaksempurnaan pasar keuangan. Para siswa menghadapi masalah untuk menutupi biaya-biaya hidupnya apabila mereka tidak memiliki kesempatan untuk meminjam dana dari lembaga keuangan, atau memperoleh dukungan dana dari pihak keluarga. Adanya bantuan finansial (misalnya dalam bentuk beasiswa), akan mendorong kendala anggaran menjadi lebih tinggi. Dengan perkataan lain, jumlah anggaran dana yang dimiliki siswa relatif lebih besar, untuk dialokasikan ke berbagai aktifitas.

Dalam model statis penawaran tenaga kerja, keadaan ini diprediksi akan meningkatkan alokasi waktu untuk belajar dan mencari hiburan. Apabila prediksi dari model miopik ini berlaku pada setiap periode (dengan perkataan lain, siswa menentukan pilihan aktifitas yang optimal setiap semester), waktu yang lebih pendek untuk memperoleh gelar dapat diharapkan. Apabila seorang siswa perlu mengerahkan segala upaya untuk menyelesaikan studi secara lebih memuaskan, masih ada kemungkinan bahwa ia tidak menggunakan waktu yang lebih banyak untuk studi, meskipun kendala anggaran tidak dipertimbangkan lagi.

\section{METODE DAN MATERIAL}

Untuk menentukan efek beasiswa terhadap masa studi mahasiswa di UAI, penelitian ini memanfaatkan model-model ekonometrika yang menggunakan informasi durasi waktu hingga terjadinya suatu kejadian, di dalam data yang dipakai. Untuk setiap mahasiswa yang masuk UAI pada tahun ajaran tertentu, probabilitas mahasiswa itu akan menyelesaikan studinya dalam masa tertentu dimodelkan. Dalam model-model yang melibatkan peubah waktu, penetapan satuan waktu mengambil peranan penting dalam menentukan model yang sesuai untuk digunakan. Meskipun lulus dari perguruan tinggi dapat terjadi pada waktu kapanpun, namun biasanya masa studi diukur dalam satuan enam bulan (atau semester). Dalam penelitian ini, masa studi diukur dalam satuan semester, dan untuk menangkap perilaku waktu kelulusan mahasiswa yang tidak tepat pada awal atau akhir suatu semester (misalnya pada pertengahan suatu semester), model ekonometrika yang digunakan adalah model durasi waktu kontinu. Artinya masa studi mahasiswa diperlakukan sebagai peubah acak kontinu, yaitu peubah yang dapat bernilai bulat atau pecahan (misalnya 4,5 semester).

Misalkan $M_{j}$ adalah tahun ajaran di mana individu $j$ memulai studinya di UAI, dan $K_{j}$ adalah waktu berakhirnya pengamatan untuk individu tersebut. Misalkan untuk kepentingan sampling, ditetapkan masa pengamatan mulai dari waktu $M$ $\left(M \leq M_{j}\right)$ hingga waktu $K\left(K \geq K_{j}\right)$. Seorang mahasiswa yang masuk pada tahun ajaran $M_{j}$ dan berhasil lulus dari UAI sebelum atau tepat pada waktu $K$, masa studinya dicatat sebesar $K_{j}-M_{j}$, dan status masa studinya (misalkan $S j$ adalah status masa studi mahasiswa) dikatakan teramati, atau $S_{j}=$ 1. Apabila sampai waktu $K$, seorang mahasiswa yang memulai studi pada tahun ajaran $M_{j}$ belum juga lulus dari UAI, masa studi mahasiswa ini tidak dapat diketahui dengan pasti. Untuk mahasiswa dengan kasus seperti ini, yang dapat dicatat hanya durasi waktu pengamatan sejak ia memulai studi hingga masa pengamatan berakhir (atau $K-M_{j}$ ), dan status masa studinya dikatakan tersensor kanan. Dalam kasus ini $S_{j}=0$.

Misalkan $T_{j}$ merepresentasikan selisih waktu antara akhir masa pengamatan dan tahun ajaran mahasiswa $j$ memulai studinya di UAI. Dalam penelitian ini, $T_{j}$ dapat bernilai $K-M, K_{j}-M_{j}, K-$ 
$M_{j}$, atau $K_{j}-M$, bergantung kapan seorang mahasiswa memulai studinya dan kapan terakhir kali diamati. Secara umum dapat ditulis sebagai $T_{j}$ $=\min (K j-M j, K-M)$. Untuk sampel berukuran $n$, dan untuk $j=1,2, \ldots, n, T_{j}$ diasumsikan saling bebas dan memiliki distribusi peluang yang identik, dengan fungsi densitas $f(t)$ dan fungsi survival $S(t)$. Misalkan data yang kita miliki adalah $\left(T_{j}, S_{j}, Z_{j}(t)\right)$ untuk $j=1,2, \ldots \ldots, n$, di mana $T_{j}$ dan $S_{j}$ seperti didefinisikan sebelumnya, dan $\boldsymbol{Z}_{j}(t)=\left(Z_{j 1}(t), \ldots\right.$, $\left.Z_{j p}(t)\right)^{t}$ adalah vektor peubah penjelas atau faktor risiko dari individu $j$ pada waktu $t$, yang dianggap memengaruhi distribusi peluangnya untuk tetap studi di UAI. Dalam penelitian ini, $Z_{j k}(t), k=1,2$, . $\ldots, p$, dapat berupa time-dependent covariates yang nilainya dapat berubah-ubah antar waktu, seperti berapa lama beasiswa yang diperoleh hingga akhir masa studi, atau berupa fixed-time covariates yang nilainya tetap dan sudah diketahui sejak awal masa pengamatan, seperti jenis kelamin dan bidang studi yang diambil.

Masa studi mahasiswa, dalam riset ini, dianggap dapat dijelaskan oleh besaran beasiswa, karakteristik individu dan latar belakang keluarga, serta bidang studi yang dipilih, melalui model regresi hazard proposional sebagai berikut:

$$
\begin{aligned}
& h(t \mid \boldsymbol{Z}(t))=h_{0}(t) \exp \left(\boldsymbol{\beta}^{t} \boldsymbol{Z}(t)\right)= \\
& h_{0}(t) \exp \left(\beta_{1} Z_{1}(t)+\ldots+\beta_{p} Z_{p}(t)\right)
\end{aligned}
$$

di mana $h_{0}(t)$ adalah baseline hazard rate yang berlaku untuk semua individu, terlepas dari karakteristik mereka, $h(t \mid \mathbf{Z}(t))$ adalah hazard rate individu dengan vektor karakteristik $\boldsymbol{Z}(t)$, dan $\boldsymbol{\beta}=$ $\left(\beta_{1}, \ldots, \beta_{p}\right)^{t}$ adalah vektor parameter. Hazard rate $h(t \mid \boldsymbol{Z}(t))$ menyatakan peluang mahasiswa dengan vektor karakteristik $\boldsymbol{Z}(t)$, berhasil lulus dari UAI, apabila diketahui telah menempuh studi selama $t$ periode.

Dalam model (3.1), bentuk parametrik diasumsikan hanya muncul pada efek kovariat terhadap hazard rate saja, sedangkan baseline hazard dianggap bersifat nonparametrik. Dengan perkataan lain peubah masa studi dianggap tidak terdistribusi menurut distribusi parameterik tertentu, seperti eksponensial dan Weibull.

Model (3.1) merupakan bagian dari model regresi hazard semiparamterik yang diusulkan oleh Cox (1972). Keunggulan dari model semiparamterik adalah tidak dibutuhkannya asumsi distribusional untuk peubah waktu yang menjadi interest penelitian. Model Cox juga disebut model hazard proporsional, karena apabila terdapat dua individu, misalkan $A$ dan $B$, dengan nilai-nilai kovariat $\boldsymbol{Z}_{a}$ dan $\boldsymbol{Z}_{b}$, nisbah hazard rate mereka adalah

$$
\begin{aligned}
& h\left(t \mid \mathbf{Z}_{a}(t)\right) / h\left(t \mid \mathbf{Z}_{b}(t)\right)=h_{0}(t) \exp (\boldsymbol{\beta} \\
& \left.\boldsymbol{Z}_{a}(t)\right) / h_{0}(t) \exp \left(\boldsymbol{\beta}^{t} \boldsymbol{Z}_{b}(t)\right) \\
& =\exp \left[\beta 1\left(Z_{1 a}(t)-Z_{1 b}(t)\right)+\ldots+\beta_{p}\left(Z_{p a}(t)-\right.\right. \\
& \left.\left.Z_{p b}(t)\right)\right],(3.2)
\end{aligned}
$$

yang pada dasarnya konstan dan proporsional terhadap karakteristik mereka masing-masing. Persamaan (3.3) juga disebut risiko relatif dari mereka yang memiliki karakterisk $Z_{a}$ terhadap mereka yang berkarakteristik $Z_{b}$. Secara khusus, apabila Z1 mengindikasikan status tertentu (misalkan $Z_{1}=1$ jika individu berjenis kelamin lelaki, dan $Z_{1}=0$ jika jenis kelaminnya perempuan), dan peubah-peubah penjelas yang lain bernilai sama, maka $h\left(t \mid \mathbf{Z}_{a}(t)\right) / h\left(t \mid \mathbf{Z}_{b}(t)\right)=\exp \left(\beta_{1}\right)$ menjelaskan risiko relatif dari individu yang berjenis kelamin lelaki dibandingkan mereka yang berjenis kelamin perempuan.

Apabila terdapat sampel acak berukuran $n$, penaksiran parameter-parameter pada model (3.1) dapat dilakukan dengan menggunakan metode kemungkinan maksimum (maximum likelihood atau ML), dengan terlebih dahulu mendefinisikan fungsi likelihood yang sesuai. Misalkan $t_{1}<t_{2}<\ldots<t_{D}$ menyatakan waktu-waktu terjadinya kelulusan mahasiswa dari UAI. Misalkan $d_{i}$ adalah banyaknya siswa yang lulus pada waktu $t_{i}$, dan $D_{i}$ adalah himpunan semua siswa yang lulus pada waktu $t_{i}$. Misalkan $\boldsymbol{s}_{i}$ adalah jumlah dari vektor $\boldsymbol{Z}_{j}$ untuk seluruh siswa yang lulus pada waktu $t_{i}$. Dengan perkataan lain $\boldsymbol{s}_{i}=\sum_{j \in D i} \mathrm{Zj}$. Selanjutnya, misalkan $R_{i}$ adalah himpunan semua siswa yang berpotensi lulus pada waktu $t_{i}$. Berbekal informasi tadi, Breslow (1974) mengusulkan fungsi likelihood parsial seperti dituangkan dalam Klein dan Moeschberger (2003):

$$
\left.\mathrm{L}(\boldsymbol{\beta})=\prod_{i=1, \ldots, D} \exp \left(\boldsymbol{\beta}^{t} \boldsymbol{s}_{i}\right) / \sum_{j \in R i} \exp \left(\boldsymbol{\beta}^{t} \boldsymbol{Z}_{j}\right)\right]^{d i}
$$

Likelihood ini mempertimbangkan setiap kejadian kelulusan terjadi pada waktu tertentu secara spesifik. Apabila terdapat beberapa individu dengan waktu lulus yang bersamaan, aproksimasi likelihood seperti ini mudah diterapkan dan dapat bekerja dengan baik. Selain itu likelihood Breslow ini juga sudah diimplementasi di berbagai paket perangkat lunak statistika. Fungsi coxph pada paket program SPlus atau $\mathrm{R}$ dapat membantu kita untuk menemukan taksiran ML untuk parameterparameter model Cox, dengan mencari nilai-nilai parameter yang memaksimumkan likelihood parsial pada (3.3). Ini dapat dilakukan baik pada data durasi waktu yang lengkap atau tersensor kanan. 
Tabel 1. Statistik deskriptif dari peubah-peubah yang

\begin{tabular}{|l|r|r|r|}
\multicolumn{1}{|c|}{ digunakan } \\
\hline \multicolumn{1}{|c|}{ Peubah } & $\begin{array}{r}\text { Semua } \\
\text { Siswa }\end{array}$ & $\begin{array}{r}\text { Penerima } \\
\text { Beasiswa }\end{array}$ & $\begin{array}{r}\text { Bukan } \\
\text { Penerima } \\
\text { Beasiswa }\end{array}$ \\
\hline \hline Karakteristik beasiswa & & & \\
\hline Besar beasiswa per bulan (Rp & & & \\
O00) & 59.30 & 155.00 & 0.00 \\
\hline Durasi beasiswa (bulan) & 8.03 & 21.00 & 0.00 \\
\hline Karakteristik individu & & & \\
\hline Usia saat masuk UAl & 18.58 & 18.69 & 18.51 \\
\hline Menikah & 0.02 & 0.01 & 0.03 \\
\hline Lelaki & 0.54 & 0.53 & 0.54 \\
\hline diploma & 0.41 & 0.35 & 0.45 \\
\hline Latar belakang keluarga & & & \\
\hline Penghasilan ortu (Rp 000) & 3919.10 & 2375.00 & 4876.00 \\
\hline ortu sma & 0.45 & 0.31 & 0.54 \\
\hline ortu pns & 0.45 & 0.63 & 0.34 \\
\hline ortu swasta & 0.49 & 0.29 & 0.62 \\
\hline Outcome & & & \\
\hline Tersensor Kanan & 0.46 & 0.42 & 0.49 \\
\hline Menyelesaikan studi & 0.54 & 0.58 & 0.51 \\
\hline Waktu dalam semester & & & \\
\hline hingga lulus & 10.32 & 10.02 & 10.51 \\
\hline hingga tersensor kanan & 8.72 & 9.74 & 8.09 \\
\hline Jumlah Siswa & 345 & 132 & 213 \\
\hline
\end{tabular}

Tabel 1 menyajikan deskripsi statistik untuk peubah-peubah penjelas utama yang digunakan dalam penelitian ini. Kolom pertama, bila tidak ada keterangan, menjelaskan rerata dari seluruh anggota sampel. Dua kolom berikutnya menyajikan informasi yang sama, namun dibedakan antara siswa yang tidak pernah dan yang minimal pernah satu kali memperoleh beasiswa dalam masa studinya. Definisi dari peubah-peubah tersebut disajikan pada Tabel 2 (lihat lampiran)

Dari 345 mahasiswa yang menjadi anggota sampel, sekitar 40 persen dari mereka pernah memperoleh beasiswa peningkatan prestasi akademik atau beasiswa nusantara dari UAI minimal satu kali dalam masa studinya. Untuk mereka yang minimal satu kali pernah memperoleh beasiswa, masing-masing dari mereka rata-rata menerima beasiswa sebesar 155 ribu rupiah per bulan selama masa studinya. Jika digabung antara mereka yang pernah menerima beasiswa dan yang tidak pernah sama sekali, setiap orang rata-rata menerima beasiswa sekitar 60 ribu rupiah perbulan. Para mahasiswa yang pernah menjadi penerima beasiswa, rata-rata akan menerima beasiswa dalam 23 bulan sepanjang masa studinya. Namun, bila dihitung secara agregat, dengan melibatkan mereka yang tidak pernah memperoleh beasiswa, setiap mahasiswa akan menerima beasiswa rata-rata selama 8 bulan. Fakta ini paling tidak menjelaskan bahwa secara umum tidak banyak mahasiswa yang dapat memperoleh beasiswa secara terus menerus hingga masa studinya berakhir. Implikasi lain yang dapat diterangkan adalah bahwa prestasi akademik mahasiswa UAI relatif tidak stabil antar semester atau tahun akademik. Penjelasannya adalah, mengingat bahwa salah satu syarat untuk dapat menerima beasiswa pada semester-semester atau tahun-tahun akademik berikutnya adalah indeks prestasi kumulatif melebihi limit tertentu (misalnya 3,20 ), selain kondisi finansial mahasiswa, maka dapat dimaklumi apabila kemampuan mahasiswa untuk memenuhi target ini relatif berat, khususnya bagi mereka yang mengambil studi pada bidangbidang seperti teknik, sains, dan matematika.

Pendapatan perbulan orang tua siswa, pada saat siswa pertama kali masuk UAI, rata-rata Rp 3.920.000. Untuk mereka yang pernah memperoleh beasiswa, rata-rata pendapatan perbulan orang tua mereka adalah Rp 2.375.000. Sebagian besar (hampir 60 persen) orang tua mahasiswa penerima beasiswa bekerja sebagai pegawai negeri sipil (PNS), sebagian kecil bekerja sebagai karyawan swasta atau pebisnis. Fakta ini setidaknya mengindikasikan bahwa mereka yang memperoleh beasiswa, rata-rata berangkat dari keluarga dengan penghasilan kepala keluarga yang relatif rendah. Pendidikan orang tua mereka juga relatif rendah (dibawah tingkat sarjana atau diploma). Selain itu fakta ini juga menjelaskan bahwa tidak sedikit mahasiswa UAI yang berasal dari keluarga dengan strata menengah ke bawah.

Hampir lima puluh persen mahasiswa, yang dijadikan sampel dalam riset ini, belum menyelesaikan studinya pada akhir masa pegamatan (atau tersensor kanan). Sisanya telah lulus dalam masa pengamatan antara tahun akademik 2004 dan 2010. Mereka yang pernah menerima beasiswa, lebih dari empat puluh persennya belum menyelesaikan studinya pada saat pengamatan berakhir. Sementara itu mereka yang tidak pernah sama sekali menerima beasiswa selama masa studinya, juga lebih dari empat puluh persen dari mereka belum merampungkan studinya hingga akhir Agustus 2010.

Rata-rata usia mahasiswa ketika pertama kali menjadi mahasiswa UAI antara 18 hingga 19 tahun. Hanya sedikit siswa yang berstatus sudah menikah. Hampir 98 persen siswa umumnya belum menikah. Mayoritas sampel mahasiswa UAI adalah lelaki (sekitar 54 persen), dan sisanya adalah perempuan. Hampir 40 persen dari sampel mahasiswa, rata-rata sudah menyandang gelar diploma III ketika pertama kali menjadi mahasiswa UAI. 


\section{HASIL PENAKSIRAN DAN PEMBAHASAN}

Penaksiran dilakukan dengan menggunakan metode penaksiran berbasis maximum likelihood, dan dengan bentuk likelihood yang diusulkan oleh Breslow (1999). Paket statistika R, melalui fungsi coxph, digunakan untuk melakukan penaksiran ini, dengan dua skenario

Skenario pertama, kita taksir dampak dari besaran dan durasi beasiswa terhadap masa studi mahasiswa. Pada skenario ini, kita ingin mengetahui apakah besaran dan durasi beasiswa secara statistik dapat menerangkan keragaman peluang mahasiswa untuk lulus dari universitas dalam kurun waktu tertentu. Pada skenario kedua, kita libatkan informasi tentang karakteristik dan latar belakang keluarga (seperti jenis kelamin, bidang studi yang diambil, dan pendapatan orang tua), sebagai informasi perantara, dalam menaksir dampak dari pemberian beasiswa terhadap peluang seorang mahasiswa untuk lulus dalam durasi waktu tertentu.

Hasil penaksiran model proporsional hazard, dengan hanya melibatkan besaran dan durasi beasiswa disajikan pada tabel 4.1. Pada tabel tersebut, kolom satu mewakili peubah-peubah penjelas yang dipakai. Kolom dua dan tiga masingmasing menjelaskan taksiran parameter (koefisien regresi) dari setiap peubah penjelas yang bersesuaian, dan standard errornya. Kolom empat dan lima masing-masing menyatakan nilai Wald chi-square statistik dan $p$-value dari setiap taksiran parameter-parameter model.

Interpretasi koefisien regresi pada model proporsional hazard berbeda dengan interpretasi pada model regresi linier. Pada model regresi linier, suatu parameter model menerangkan besarnya dampak marginal dari suatu peubah penjelas pada realisasi peubah tak bebas. Pada model proporsional hazard, parameter-parameter model menjelaskan risiko relatif dari individu-individu yang memiliki karakteristik tertentu (yang dicirikan oleh realisasi nilai peubah penjelas), untuk mengalami suatu jenis kejadian, dibandingkan mereka yang tidak memiliki karakteristik tersebut. Parameter dari model hazard proporsional, juga dapat menjelaskan ekses risiko relatif dari individuindividu yang berperilaku tertentu dengan ciri tertentu (misalnya berjenis kelamin lelaki), dibandingkan mereka yang berperilaku tertentu dengan ciri yang lain (misalnya berjenis kelamin perempuan).

Wald chisquare menjelaskan nilai statistik uji Wald yang digunakan untuk memutuskan apakah hipotesa nul pada pengujian-pengujian keabsahan parameter, ditolak atau tidak. hipotesa nul ditolak apabila nilai statistik uji Wald secara absolut melebihi nilai kritis tertentu. Sementara itu $p$-value menerangkan peluang bahwa peubah statistik uji memiliki nilai di atas nilai statistik uji Wald (yang diperoleh dari informasi sampel). Hipotesa nul akan ditolak apabila $p$-value lebih kecil dibandingkan tingkat kebermaknaan statistik tertentu, yang biasanya bernilai 0,05 atau 0,01 .

Pada tabel 3 dapat dilihat bahwa taksiran koefisien regresi untuk besaran beasiswa per bulan adalah 0,6383 dengan $p$-value 0,045, sedangkan untuk durasi beasiswa adalah 0,9476 dengan $p$ value 0,025. Dengan asumsi bahwa tingkat kebermaknaan ditetapkan sebesar 5\%, maka kedua peubah beasiswa ini, masing-masing secara statistik bermakna (significant) dalam menerangkan masa studi mahasiswa. Risiko relatif untuk peubah besaran beasiswa adalah 1,89. Ini menjelaskan bahwa mahasiswa yang memperoleh beasiswa perbulan dengan nilai 1 satuan (1000 rupiah) lebih tinggi, peluang mahasiswa tersebut menyelesaikan studi diperkirakan 89 persen lebih besar dibandingkan mereka yang memperoleh beasiswa dengan nilai 1 satuan lebih rendah, meskipun durasi mereka memperoleh beasiswa sama lamanya.

Risiko relatif untuk peubah durasi perolehan beasiswa adalah 2,58. Hal ini menjelaskan bahwa dua kelompok mahasiswa dengan besaran perolehan beasiswa perbulan yang sama, mahasiswa yang memperoleh beasiswa dengan durasi 1 satuan (satu bulan) lebih lama, peluang mahasiswa tersebut menyelesaikan studi diperkirakan 150 persen lebih besar dibandingkan mereka yang memperoleh beasiswa dengan durasi yang lebih sebentar.

Tabel 3. Hasil penaksiran model proporsional hazard dengan karakteristik beasiswa sebagai peubah-peubah penjelas

\begin{tabular}{|l|r|r|r|r|r|}
\hline \multicolumn{1}{|c|}{ Peubah } & $\begin{array}{c}\text { Taksiran } \\
\text { parameter }\end{array}$ & $\begin{array}{c}\text { Standard } \\
\text { error }\end{array}$ & $\begin{array}{c}\text { Wald Chi } \\
\text { Square }\end{array}$ & p-Value & $\begin{array}{c}\text { Relative } \\
\text { risk }\end{array}$ \\
\hline \hline $\begin{array}{l}\text { Besar beasiswa per } \\
\text { bulan (Rp 000) }\end{array}$ & 0.6383 & 0.3190 & 4.0038 & 0.0454 & 1.8933 \\
\hline Durasi beasiswa (bulan) & 0.9476 & 0.4222 & 5.0375 & 0.0248 & 2.5795 \\
\hline
\end{tabular}

Sumber: hasil olahan sendiri dengan menggunakan program $R$

Untuk menyelidiki dampak interaksi besaran dan durasi beasiswa pada masa studi mahasiswa, kami lakukan penaksiran parameter model proporsional hazard, dengan melibatkan peubah total nilai beasiswa yang diterima selama masa studi, sebagai peubah penjelas di dalam model. Peubah ini merupakan perkalian antara besaran beasiswa per bulan dan durasi beasiswa yang diperoleh mahasiswa selama masa studinya. Hasil 
penaksiran parameter untuk model ini disajikan dalam tabel 4.

Tabel 4. Hasil penaksiran model proporsional hazard dengan total nilai beasiswa selama masa studi sebagai peubah penjelas.

\begin{tabular}{|l|r|r|r|r|r|}
\hline \multicolumn{1}{|c|}{ Peubah } & $\begin{array}{c}\text { Taksiran } \\
\text { parameter }\end{array}$ & $\begin{array}{c}\text { Standard } \\
\text { error }\end{array}$ & $\begin{array}{c}\text { Wald Chi } \\
\text { Square }\end{array}$ & p-Value & $\begin{array}{c}\text { Relative } \\
\text { risk }\end{array}$ \\
\hline \hline $\begin{array}{l}\text { Total nilai beasiswa } \\
\text { yang diterima (Rp 000) }\end{array}$ & 0.857 & 0.4108 & 4.3521 & 0.036963 & 2.356082 \\
\hline
\end{tabular}

Pada tabel 4 taksiran koefisien regresi untuk total nilai beasiswa selama masa studi adalah 0,857 dengan $p$-value 0,0369. Dengan asumsi bahwa tingkat kebermaknaan adalah 5\%, maka peubah ini secara statistik bermakna (significant) dalam menerangkan masa studi mahasiswa. Risiko relatif untuk peubah besaran beasiswa adalah 2,36. Besaran ini menjelaskan bahwa mahasiswa yang memperoleh total nilai beasiswa dengan besaran 1 satuan (1000 rupiah) lebih tinggi selama masa studinya, peluang mahasiswa tersebut menyelesaikan studi dalam periode waktu tertentu diperkirakan 136 persen lebih besar dibandingkan mereka yang memperoleh total nilai beasiswa dengan besaran yang lebih rendah.

Berdasarkan hasil-hasil empiris ini secara umum dapat dijelaskan bahwa fasilitas beasiswa yang diperkenalkan oleh UAI, secara statistik efektif dalam memberikan insentif bagi mahasiswa untuk merampungkan studinya secara lebih cepat. Ini ditunjukkan dengan fakta empiris bahwa mereka yang memperoleh beasiswa rata-rata memiliki peluang yang lebih besar untuk lulus dari UAI dalam periode tertentu, atau dengan perkataan lain memilki kemungkinan untuk menyelesaikan studinya lebih cepat. Skema beasiswa yang digelontorkan oleh UAI setidaknya berhasil memberikan dorongan bagi mahasiswa untuk lebih fokus dalam menjalani perkuliahan, sehingga diharapkan mampu menyelesaikan studi secara lebih cepat.

Untuk menyelidiki apakah keragaman peluang seseorang lulus dari UAI dalam periode waktu tertentu, tidak hanya dipengaruhi oleh skema beasiswa yang diterima, namun juga oleh karakteristik individu dan stimulan yang lain, kami mencoba untuk melibatkan karakteristik individu dan latar belakang mahasiswa, serta bidang studi yang diambil oleh mahasiswa, sebagai peubahpeubah penjelas tambahan dalam menaksir dampak pemberian beasiswa pada masa studi mahasiswa UAI. Peubah-peubah ini kami anggap dapat menjembatani perilaku dampak pemberian beasiswa pada masa studi mahasiswa. Hasil penaksiran model proporsional hazard dengan melibatkan karakteristik individu, latar belakang keluarga, dan bidang studi yang diambil sebagai peubah-peubah penjelas, disajikan dalam tabel 5 .

Tabel 5. Hasil penaksiran model proporsional hazard dengan melibatkan karakteristik individu, keluarga, dan bidang studi yang diambil mahasiswa sebagai peubah penjelas.

\begin{tabular}{|c|c|c|c|c|c|c|}
\hline Peubah & $\begin{array}{c}\text { Taksiran } \\
\text { parameter }\end{array}$ & $\begin{array}{c}\text { Standard } \\
\text { error }\end{array}$ & $\begin{array}{l}\text { Wald Chi } \\
\text { Square }\end{array}$ & $p$-Value & $\begin{array}{c}\text { Relative } \\
\text { risk }\end{array}$ & $\begin{array}{c}\text { Test } \\
\text { status }\end{array}$ \\
\hline \multicolumn{7}{|l|}{ Karakteristik beasiswa } \\
\hline $\begin{array}{l}\text { Besar beasiswa per bulan } \\
\text { (Rp 000) }\end{array}$ & -0.009 & 0.005 & 3.269 & 0.071 & 0.991 & \\
\hline Durasi beasiswa (bulan) & 0.003 & 0.001 & 5.310 & 0.021 & 1.003 & sig \\
\hline \multicolumn{7}{|l|}{ Karakteristik individu } \\
\hline Usia saat masuk UAI & -0.002 & 0.002 & 1.002 & 0.317 & 0.998 & \\
\hline Menikah & -0.134 & 0.090 & 2.201 & 0.138 & 0.875 & \\
\hline Lelaki & 0.005 & 0.008 & 0.389 & 0.533 & 1.005 & \\
\hline diploma & 0.078 & 0.032 & 5.924 & 0.015 & 1.081 & sig \\
\hline \multicolumn{7}{|l|}{ Latar belakang keluarga } \\
\hline Penghasilan ortu (Rp 000) & -0.089 & 0.056 & 2.516 & 0.113 & 0.915 & \\
\hline ortu sma & -0.012 & 0.008 & 2.277 & 0.131 & 0.988 & \\
\hline ortu pns & -0.154 & 0.087 & 3.146 & 0.076 & 0.857 & \\
\hline ortu swasta & 0.025 & 0.015 & 2.710 & 0.100 & 1.025 & \\
\hline \multicolumn{7}{|l|}{$\begin{array}{l}\text { Bidang studi (basis = } \\
\text { ekonomi) }\end{array}$} \\
\hline sains dan teknik & 0.018 & 0.012 & 2.210 & 0.137 & 1.018 & \\
\hline hukum & 0.038 & 0.015 & 6.505 & 0.011 & 1.039 & sig \\
\hline sastra & 0.054 & 0.027 & 4.073 & 0.044 & 1.056 & sig \\
\hline psikodik & 0.149 & 0.085 & 3.084 & 0.079 & 1.161 & \\
\hline isip & 0.065 & 0.031 & 4.376 & 0.036 & 1.067 & sig \\
\hline
\end{tabular}

Sumber: Hasil olahan sendiri dengan paket program $R$

Pada tabel 5, setelah kita mempertimbangkan karakteristik individu dan karakteristik keluarga dari mahasiswa, besaran beasiswa yang diterima perbulan tidak lagi bermakna ( $\mathrm{p}$-value $>5 \%$ ) secara statistik, dalam menerangkan keragaman masa studi mahasiswa, measkipun apabila kita gunakan tingkat kebermaknaan statistik $10 \%$, hasilnya menjadi bermakna. Risiko relatif ditaksir bernilai 0,991. Terlepas dari bermakna atau tidaknya peubah besaran beasiswa perbulan secara statistik, berdasarkan angka risiko relatif, paling tidak dapat dijelaskan bahwa apabila terdapat dua mahasiswa dengan karakteristik individu, latar belakang keluarga, dan bidang studi yang sama, mahasiswa yang mendapatkan beasiswa dengan nilai 1 satuan (Rp 1000) lebih besar, diperkirakan akan memiliki peluang 1 persen lebih kecil, untuk lulus pada periode tertentu, dibandingkan mahasiswa yang mendapatkan beasiswa dengan nilai yang lebih rendah.

Sebaliknya, peubah durasi beasiswa tetap bermakna, secara statistik, dalam menerangkan keragaman peluang lulus dari universitas (p-value < $5 \%$ ), meskipun kita telah melibatkan sejumlah karakteristik tentang mahasiswa dalam penaksiran model. Risiko relatif dari peubah durasi perolehan beasiswa adalah 1,003. Hal ini menjelaskan bahwa dua kelompok mahasiswa dengan karakteristik 
individu, latar belakang keluarga, bidang studi, dan besaran perolehan beasiswa perbulan yang sama, mahasiswa yang memperoleh beasiswa dengan durasi 1 satuan (satu bulan) lebih lama, peluang mahasiswa tersebut menyelesaikan studi diperkirakan 3 permil lebih besar dibandingkan mereka yang memperoleh beasiswa dengan durasi yang lebih sebentar.

Dari empat peubah penjelas yang menjadi bagian dari karaketristik individu mahasiswa, hanya satu peubah yang bermakna dalam menerangkan keragaman masa studi mahasiswa. Peubah ini adalah indikator apakah mahasiswa sebelum menempuh studi di UAI, pernah menempuh pendidikan paling tidak pada tingkat diploma tiga. Risiko relatif dari peubah ini adalah 1,081. Hal ini menjelaskan bahwa apabila terdapat dua kelompok mahasiswa dengan karakteristik beasiswa, latar belakang keluarga, dan bidang studi yang sama, mahasiswa yang sudah lulus setidaknya dari program diploma tiga sebelum masuk UAI, diperkirakan memiliki peluang untuk menyelesaikan studi dalam kurun waktu tertentu, 81 persen lebih tinggi dibandingkan mereka yang ketika masuk UAI, belum pernah lulus minimal dari program diploma tiga.

Meskipun tiga peubah lain dalam karakteristik individu tidak bermakna secara statistik dalam menerangkan keragaman masa studi mahasiswa, namun taksiran koefisien risiko aau besaran risiko relatif untuk ketiga peubah ini, masing-masing memperlihatkan arah hubungan yang relatif masuk akal. Misalnya, mahasiswa lelaki diperkirakan memiliki risiko relatif sebesar 1,005. Ini menjelaskan bahwa mahasiswa lelaki diperkirakan memiliki peluang untuk lulus lebih besar dalam periode tertentu, dibandingkan mahasiswa perempuan, apabila hal-hal yang lain tidak berbeda. Dengan perkataan lain, mahasiswa lelaki secara rata-rata diperkirakan memiliki masa studi yang lebih cepat dibandingkan mahasiswa perempuan, meskipun perbedaaan peluangnya tidak begitu besar (hanya sebesar 0,5 persen) dan tidak bermakna.

Seluruh peubah yang mewakili latar belakang keluarga juga tidak bermakna secara statistik dalam menerangkan keragaman masa studi mahasiswa. $P$ value untuk taksiran koefisien regresi dari setiap peubah ini lebih besar dari 5 persen. Penghasilan perbulan dari orang tua mahasiswa pada saat mahasiswa masuk UAI, pendidikan tertingginya, dan jenis pekerjaannya, secara statistik tidak didukung oleh data yang memadai untuk menegaskan bahwa mereka berpengaruh pada masa studi mahasiswa. Terlepas dari ketidakbermaknaan dari peubah-peubah karakteristik orang tua ini, beberapa temuan yang diperoleh dari hasil-hasil penaksiran, mengisyaratkan bahwa mahasiswa yang pendidikan orangtuanya paling tinggi adalah SMA, diperkirakan memiliki peluang yang lebih rendah (meskipun perbedaannya sangat kecil) untuk menyelesaikan studi secara tepat waktu dibandingkan mereka yang pendidikan orangtuanya lebih rendah, meskipun kondisi yang lain dari mahasiswa-mahasiswa itu setara.

Peubah penjelas lain, yang dipandang ikut memengaruhi masa studi mahasiswa, baik yang pernah maupun yang belum pernah memperoleh beasiswa adalah bidang studi yang ditempuh oleh mahasiswa. Karena peubah bidang studi merupakan peubah kategorik, kami bagi peubah ini menjadi lima peubah boneka, yang masing-masing mewakili indikator bidang studi yang ditempuh oleh mahasiswa (untuk rincian dan definisi dari peubahpeubah boneka ini, lihat lampiran). Hasil penaksiran dengan menggunakan metode ML, dengan bentuk likelihood seperti diusulkan oleh Breslow (1974), menerangkan bahwa hanya tiga peubah dari lima peubah boneka yang bermakna, pada tingkat kebermaknaan statistik 5 persen, dalam menjelaskan keragaman masa studi mahasiswa. Ketiga peubah ini adalah indikator bidang studi hukum, sastra, dan ilmu sosial dan ilmu politik (ISIP). Taksiran risiko relatif dari peubah-peubah ini masing-masing adalah 1,039, 1,056, dan 1,067. Besaran risiko relatif seperti ini mengindikasikan bahwa mahasiswa yang mengambil bidang studi hukum, atau sastra, atau ISIP diperkirakan memiliki peluang relatif lebih besar (masing-masing sebesar 4, 6, dan 7 persen), untuk merampungkan studinya di UAI secara tepat waktu, dibandingkan rekan-rekan mereka yang mengambil bidang studi lain, meskipun mereka sama-sama memperoleh besaran dan durasi beasiswa yang sepadan.

Secara implisit temuan ini memberikan penjelasan bahwa mahasiswa yang menempuh studi di bidang-bidang seperti sains dan teknologi, atau ekonomi, memiliki peluang yang lebih kecil untuk lulus secara tepat waktu, dibandingkan rekan-rekan mereka yang menempuh studi di bidang yang lain.

Untuk melihat seberapa besar peluang kelulusan mahasiswa pada semester-semester tertentu, terlepas dari status beasiswa, karakteristik individu, keluarga, dan bidang studi yang diambil, kami taksir baseline hazard kelulusan secara nonparametrik, dengan menggunakan metode Nelson-Aalen (1978), dengan asumsi bahwa semester 1 sampai dengan 8 sebagai basis masa 
kelulusan. Hasil penaksiran baseline hazard kelulusan dapat dilihat pada tabel 6.

Tabel 6. Hasil penaksiran Baseline Hazard untuk Kelulusan dengan Kelulusan di semester 1 hingga 8 sebagai basis hazard.

\begin{tabular}{|l|r|r|r|r|r|r|}
\hline \multicolumn{1}{|c|}{ Peubah } & $\begin{array}{c}\text { Taksiran } \\
\text { parameter }\end{array}$ & $\begin{array}{c}\text { Standard } \\
\text { error }\end{array}$ & $\begin{array}{c}\text { Wald Chi } \\
\text { Square }\end{array}$ & p-Value & $\begin{array}{c}\text { Relative } \\
\text { risk }\end{array}$ & \multicolumn{1}{c|}{$\begin{array}{c}\text { Test } \\
\text { status }\end{array}$} \\
\hline \hline $\begin{array}{l}\text { Baseline Hazard Kelulusan (Base: } \\
\text { kelulusan dalam semester 1 - 8) }\end{array}$ & & & & & & \\
Kelulusan di semester 9 - 10 & 0.148 & 0.075 & 3.871 & 0.049 & 1.159 & $\mathrm{sig}$ \\
Kelulusan di semester 11 - 12 & 0.252 & 0.129 & 3.826 & 0.050 & 1.287 & $\mathrm{sig}$ \\
$\begin{array}{l}\text { Kelulusan di semester 13 dan } \\
\text { setelahnya }\end{array}$ & 0.369 & 0.184 & 4.033 & 0.045 & 1.447 & $\mathrm{sig}$ \\
\hline
\end{tabular}

Hasil penaksiran secara umum menjelaskan baseline hazard untuk mengalami kelulusan meningkat dengan lamanya masa studi. Peluang seorang mahasiswa dapat lulus dari UAI, setelah menempuh studi selama 9 hingga 10 semester, diperkirakan meningkat 16 persen dibandingkan apabila ia baru menempuh studi selama 8 semester. Sementara itu peluang mahasiswa untuk lulus semakin besar, apabila ia telah menempuh studi lebih lama dari 10 semester. Peluang seorang mahasiswa lulus dari UAI, setelah menempuh studi selama 11 hingga 12 semester, diperkirakan meningkat 28 persen dibandingkan apabila ia baru menempuh studi selama 8 semester. Apabila seorang mahasiswa telah menempuh studi selama 13 semester atau lebih, peluang mahasiswa itu lulus dari UAI, diperkirakan meningkat 45 persen dibandingkan apabila ia baru menempuh studi selama 8 semester.

\section{KESIMPULAN}

Penelitian ini bertujuan untuk menganalisa dan menyelidiki bagaimana pemberian beasiswa memengaruhi waktu kelulusan mahasiswa di perguruan tinggi. Penelitian ini berfokus pada peluang mahasiswa untuk menyelesaikan studinya pada kurun waktu tertentu. Kami gunakan model durasi yang memungkinkan kita untuk menganalisa peluang seorang mahasiswa untuk lulus setelah menempuh studi selama periode waktu tertentu. Ruang lingkup penelitian ini difokuskan pada skema beasiswa yang ditawarkan oleh Universitas AlAzhar Indonesia (UAI) untuk membantu para mahasiswa atau calon mahasiswa yang berasal dari keluarga berpenghasilan rendah, agar dapat melanjutkan studinya di UAI.

Secara teoritis, dampak pemberian beasiswa pada masa studi mahasiswa bersifat ambigu. Ada banyak pendapat dan mazhab tentang bagaimana dampak pemberian beasiswa pada masa studi mahasiswa. Untuk menjawab pemasalahan ini, kami coba lakukan kajian empiris pada mahasiswa UAI yang mulai masuk UAI sejak tahun akademik 2004/2005 hingga 2007/2008, dengan menerapkan model durasi semiparametrik dengan satu status keluar (yaitu lulus dari UAI).

Temuan-temuan utama kami adalah bahwa secara umum pemberian beasiswa memengaruhi masa studi secara terbalik. Peningkatan besaran beasiswa sebesar 1 satuan (Rp 1000) diperkirakan memperbesar peluang mahasiswa untuk lulus kuliah sebesar 90 persen, sedangkan peningkatan dalam durasi beasiswa sebesar 1 satuan (1 bulan) diperkirakan memperbesar peluang mahasiswa untuk lulus kuliah sebesar 150 persen, atau masa studi mereka menjadi lebih pendek. Penyelidikan lebih lanjut terhadap interaksi besaran dan durasi beasiswa menjelaskan bahwa peningkatan dalam total perolehan beasiswa sebesar 1 satuan (Rp 1000) diperkirakan memperbesar peluang mahasiswa untuk lulus kuliah dalam periode waktu tertentu, sebesar hampir 140 persen.

Selain temuan-temuan utama ini, kami peroleh beberapa temuan tambahan bahwa meskipun samasama masuk dalam skema beasiswa dengan besaran dan durasi yang sama, masa studi dari dua orang mahasiswa secara statistik dapat berbeda, apabila karakteristik individu, latar belakang keluarga, dan bidang studi mereka berbeda. Mahasiswa dengan gelar akademik minimal diploma tiga memiliki peluang lebih besar untuk lulus dalam periode tertentu, dibandingkan mereka yang benar-benar baru lulus dari SMA ketika pertama kali menjadi mahasiswa UAI. Meskipun latar belakang keluarga tidak bermakna secara statistik, diperoleh temuan bahwa mahasiswa yang pendidikan orangtuanya paling tinggi adalah SMA, diperkirakan memiliki peluang yang lebih rendah (meskipun perbedaannya sangat kecil) untuk menyelesaikan studi secara tepat waktu dibandingkan mereka yang 
pendidikan orangtuanya lebih rendah. Bidang studi yang dipilih diduga juga ikut berkontibusi pada masa studi mahasiswa. Meskipun dua orang mahasiswa memperoleh beasiswa dengan skema yang sama, masa studi mereka dapat berbeda apabila bidang studi yang mereka pilih berbeda. Mahasiswa-mahasiswa di fakultas sastra, sosial dan politik, atau hukum memiliki peluang sedikit lebih besar untuk lulus dari UAI pada periode tertentu dibandingkan rekan-rekan mereka di fakultas lain. Temuan ini sependapat dengan beberapa temuan di luar negeri yang menggunakan sampel mahasiswa pascasarjana bahwa pada bidang-bidang studi tertentu dibutuhkan waktu yang, secara alamiah, relatif lama bagi mahasiswa untuk menyelesaikan pendidikannya.

Peluang mahasiswa untuk lulus setelah menempuh studi selama lebih dari delapan semester, diperkirakan lebih besar dibandingkan apabila hanya menempuh studi selama delapan semester. Temuan ini sejalan dengan temuan dari riset-riset lain di luar negeri yang menggunakan sampel mahasiswa tingkat sarjana. Baseline hazard dari kelulusan cenderung lebih tinggi pada masa studi yang lebih lama.

Seluruh temuan yang diperoleh dalam penelitian ini mengindikasikan bahwa terpecahkannya kendala finansial untuk mendanai pendidikan (melalui pemberian beasiswa) dan hasrat individu untuk memperoleh penghasilan yang lebih baik dengan segera, dapat menjadi pendorong bagi mahasiswa untuk merampungkan pendidikannya di perguruan tinggi secara tepat waktu. Meskipun demikian terdapat stimulan lain, yang berasal dari individu dan keluarga mahasiswa maupun dari bidang studi yang dipilih, yang menyebabkan masa studi mahasiswa penerima beasiswa dapat beragam. Seluruh hasil penaksiran dan analisa dalam penelitian ini diperkuat oleh hasil penaksiran yang sama dengan menggunakan data masa studi mahasiswa yang tidak tersensor (tabel 7).

Tabel 7. Hasil penaksiran model proporsional hazard dengan melibatkan karakteristik individu, keluarga, dan bidang studi yang diambil mahasiswa sebagai peubah penjelas, dengan menggunakan sampel mahasiswa yang masa studinya teramati dengan lengkap.

\begin{tabular}{|c|c|c|c|c|c|c|}
\hline Peubah & $\begin{array}{c}\text { Taksiran } \\
\text { parameter }\end{array}$ & $\begin{array}{l}\text { Standard } \\
\text { error }\end{array}$ & $\begin{array}{l}\text { Wald Chi } \\
\text { Square }\end{array}$ & $p$-Value & $\begin{array}{l}\text { Relative } \\
\text { risk }\end{array}$ & $\begin{array}{l}\text { Test } \\
\text { status }\end{array}$ \\
\hline \multicolumn{7}{|l|}{ Karakteristik beasiswa } \\
\hline $\begin{array}{l}\text { Besar beasiswa per bulan } \\
(\mathrm{Rp} 000)\end{array}$ & -0.005 & 0.004 & 1.570 & 0.210 & 0.995 & \\
\hline Durasi beasiswa (bulan) & 0.005 & 0.002 & 6.219 & 0.013 & 1.005 & sig \\
\hline \multicolumn{7}{|l|}{ Karakteristik individu } \\
\hline Usia saat masuk UAI & -0.001 & 0.003 & 0.160 & 0.689 & 0.999 & \\
\hline Menikah & -0.136 & 0.080 & 2.882 & 0.090 & 0.873 & \\
\hline Lelaki & 0.008 & 0.009 & 0.784 & 0.376 & 1.008 & \\
\hline diploma & 0.075 & 0.035 & 4.605 & 0.032 & 1.078 & sig \\
\hline \multicolumn{7}{|l|}{ Latar belakang keluarga } \\
\hline Penghasilan ortu (Rp 000) & -0.069 & 0.063 & 1.212 & 0.271 & 0.933 & \\
\hline ortu sma & -0.009 & 0.007 & 1.668 & 0.197 & 0.991 & \\
\hline ortu pns & -0.126 & 0.078 & 2.591 & 0.107 & 0.882 & \\
\hline ortu swasta & 0.015 & 0.019 & 0.614 & 0.433 & 1.015 & \\
\hline \multicolumn{7}{|l|}{$\begin{array}{l}\text { Bidang studi (basis = } \\
\text { ekonomi) }\end{array}$} \\
\hline sains dan teknik & 0.019 & 0.015 & 1.574 & 0.210 & 1.019 & \\
\hline hukum & 0.031 & 0.014 & 4.755 & 0.029 & 1.031 & sig \\
\hline sastra & 0.056 & 0.025 & 5.086 & 0.024 & 1.058 & sig \\
\hline psikodik & 0.126 & 0.088 & 2.042 & 0.153 & 1.134 & \\
\hline isip & 0.072 & 0.035 & 4.270 & 0.039 & 1.075 & sig \\
\hline
\end{tabular}

Studi lebih lanjut diharapkan dapat menambah pengetahuan tentang peubah-peubah lain, yang belum dicakup dalam penelitian ini, yang diduga dapat menjelaskan efek pemberian beasiswa pada masa studi dari mahasiswa. Peubah-peubah ini misalnya adalah besarnya bantuan dana dari orang 
tua, lamanya waktu bekerja, durasi waktu belajar, dan besaran bantuan dana yang lain. Studi-studi lebih lanjut diharapkan juga dapat menangkap efek pemberian beasiswa, dengan menggunakan data panel, sehingga mampu menangkap informasi beasaran beasiswa dan atau penghasilan keluarga secara runtun waktu. Penelitian lanjutan diharapkan juga dapat menampung sampel yang lebih luas, misalnya mahasiswa-mahasiswa program sarjana di Jakarta.

\section{DAFTAR PUSTAKA}

[1] Abbring, J. H. and G. J. van den Berg (2003). "The identifiability of the mixed proportional hazards competing risks model," Journal of the Royal Statistical Society, Series B-Statistical Methodology, 65(Part 3), 701-710. ISSN 13697412.

[2] Booth, A. L. and S. E. Satchell (1995): "The Hazards of Doing a PhD: An Analysis of Completion and Withdrawal Rates of British $\mathrm{PhD}$ Students in the 1980s." Journal of the Royal Statistical Society. Series A (Statistics in Society), 158(2), 297-318.

[3] Cameron, S. V. and C. Taber (2004). "Estimation of Educational Borrowing Constraints Using Returns to Schooling." Journal of Political Economy, 112(1), 132-182.

[4] Carneiro, P. and J. J. Heckman (2002): "The Evidence on Credit Constraints in Post-Secondary Schooling." The Economic Journal, 112(482), 705734.

[5] Ehrenberg, R. G. and P. G. Mavros (1995): "Do doctoral students' financial support patterns affect their times-to-degree and completion probabilities." The Journal of Human Resources, 30(3), 581-609.

[6] Ehrenberg, R. G. and D. R. Sherman (1987): "Employment While in College, Academic Achievement, and Postcollege Outcomes: A Summary of Results." The Journal of Human Resources, 22(1), 1-23.
[7] Garibaldi, P., F. Giavazzi, A. Ichino, and E. Rettore (2007): "College Cost and Time to Complete a Degree: Evidence from Tuition Discontinuities." Discussion Paper W12863, NBER Working Paper.

[8] Hakkinen, I. and R. Uusitalo (2003): "The effect of a student aid reform on graduation: a duration analysis." Discussion paper, Uppsala University.

[9] Han, A. and J. A. Hausman (1990): "Flexible Parametric Estimation of Duration and Competing Risk Models." Journal of Applied Econometrics, 5(1), 1-28.

[10] Heineck, M., M. Kifmann, and N. Lorenz (2006): "A duration analysis of the effects of tuition fees for long term students in Germany." Working Papers of the Research Group Heterogenous Labor 06-05, Research Group Heterogeneous Labor, University of Konstanz/ZEW Mannheim.

[11] Keane, M. P. and K. I.Wolpin (2001): “The Effect of Parental Transfers and Borrowing Constraints on Educational Attainment." International Economic Review, 42(4), 1051-1103.

[12] Prentice, R., J. Kalbfleisch, A. J. Peterson, N. Flournoy, V. Farewell, and N. Breslow (1978): "The Analysis of Failure Times in the Presence of Competing Risks." Biometrics, 34(4), 541-554

[13] Shea, J. (2000): "Does parents' money matter?" Journal of Public Economics, 77(2), 155-184.

[14] Siegfried, J. and W. A. Stock (2001): "So You Want to Earn a Ph.D. in Economics: How Long Do You Think it Will Take?" Journal of Human Resources, 36(2), 364-378.

[15] Siegfried, J. J. and W. A. Stock (2006): “Time-toDegree for the Economics Ph.D. Class of 20012002." American Economic Review, 96(2), 467474.

[16] Steiner, V. and K. Wrohlich (2008): "Would Increased Financial Aid for Students Raise Enrolment into Higher Education? - New Evidence for Germany." Discussion Paper 805, DIW Berlin.

[17] Stinebrickner, R. and T. Stinebrickner (2009): “The Effect of Credit Constraints on the College Drop Out Decision: A Direct Approach Using a New Panel Study."American Economic Review, 98(5), 2163-2184. Online Publication date: 1-Jan-2009. 
Tabel 2. Definisi Variabel-Variabel Penelitian

Variabel

Karakteristik beasiswa

Besar Beasiswa

Durasi Beasiswa

Karakteristik individu

Usia

Menikah

Male

Diploma

Bidang Studi

Latar Belakang Keluarga ortu sma

ortu pns

ortu swasta

penghasilan ortu

Karakteristik masa studi

Masuk

Keluar

Status
Definisi

Besarnya beasiswa per bulan ( $\mathrm{Rp} 000)$

Jumlah bulan menerima beasiswa

Usia mahasiswa ketika masuk UAI

Peubah bonerka untuk menandai apakah siswa

berstatus menikah $(=1)$

Peubah boneka untuk menandai apakah siswa berstatus

Lelaki (=1)

Peubah boneka untuk menandai apakah siswa bergelar minimal diploma III $(=1)$ pada saat masuk UAI

Peubah-peubah boneka yang mengindikasikan apakah siswa mengambil bidang studi tertentu (misalnya variabel ekonomi akan bernilai 1 apabila siswa mengambil bidang ekonomi)

dummy variabel yang mengindikasikan apakah pendidikan tertinggi kepala keluarga adalah sma (= 1) dummy variabel yang mengindikasikan apakah pekerjaan kepala keluarga adalah pns $(=1)$ dummy variabel yang mengindikasikan apakah pekerjaan kepala keluarga adalah pegawai swasta (= 1)

besar pendapatan kepala keluarga perbulan pada saat siswa pertama kali masuk UAI

bulan dan tahun siswa masuk UAI

bulan dan tahun siswa lulus dari UAI atau Agustus 2010, mana yang lebih dahulu dummy variabel yang mengindikasikan apakah pada Agustus 2010, siswa sudah lulus (=1) dari UAI 